\title{
PENGARUH BERBAGAI DOSIS ABU JANJANG KELAPA SAWIT (AJKS) TERHADAP PERTUMBUHAN DAN PRODUKSI TANAMAN TOMAT (Solanum Iycopersicum L) DI TANAH GAMBUT
}

\author{
Zulkifli,B ${ }^{1}$, Intan Sari, SP. , MP², Zinatal Hayati, SP ${ }^{2}$ \\ Program Studi Agroteknologi Fakultas Pertanian \\ Universitas Islam Indragiri
}

\begin{abstract}
ABSTRAK
Penelitian tentang pengaruh berbagai dosis Abu Janjang Kelapa Sawit (AJKS) terhadap pertumbuhan dan produksi tanaman tomat (Solanum Iycopersicum L) di Tanah Gambut, dilakukan di Desa Rumbai Jaya, Kecamatan Kempas, Kabupaten Indragiri Hilir, Propinsi Riau. Penelitian berlangsung selama 4 bulan dari september 2014 sampai Desember 2014. Tujuan dari penelitian ini adalah 1) Mengetahui pengaruh pemberian berbagai dosis Abu Janjang Kelapa Sawit (AJKS) terhadap pertumbuhan dan produksi Tanaman tomat di tanah gambut, 2) Mendapatkan dosis Abu Janjang Kelapa Sawit (AJKS) yang terbaik bagi pertumbuhan dan produksi tanaman tomat ditanah gambut.

Penelitian dilakukan menggunakan Rancangan Acak Lengkap dengan 6 perlakuan dan 4 ulangan, yaitu dosis 0 ton/ha, dosis 0,6 ton/ha, dosis 0,9 ton/ha, dosis 1,2 ton/ha dan dosis 1,5 ton/ha. Data hasil penelitian di lakukan perhitungan statistik dengan menggunakan analisis sidik ragam dan jika terdapat pengaruh yang nyata maka di lakukan uji lanjut Tukey HSD pada taraf 5\%. Parameter yang di amati pada penelitian adalah tinggi tanaman, jumlah cabang tanaman, bobot buah pertanaman, bobot buah perbutir, jumlah buah pertanaman dan diameter buah pertanaman.

Hasil penelitian memberikan pengaruh yang nyata pada parameter tinggi tanaman, jumlah cabang tanaman, bobot buah pertanaman dan jumlah buah pertanaman, sedangkan parameter buah perbutir dan diameter buah pertanaman tidak memberikan pengaruh yang nyata. Hasil penelitian menunjukkan dosis AJKS terbaik adalah 1,5 ton/ha yang terlihat dari parameter tinggi tanaman, jumlah cabang tanaman, bobot buah pertanaman, jumlah buah pertanaman dan diameter buah pertanaman
\end{abstract}

Kata Kunci : Abu Janjang Kelapa Sawit, Tanah gambut dan Tomat

\section{ABSTRACT}

Research on the effect of various doses of Palm Oil Palm (AJKS) on the growth and production of tomato plants (Solanum Iycopersicum L) in Peatland, was conducted in Rumbai Jaya Village, Kempas District, Indragiri Hilir Regency, Riau Province. The research lasted for 4 months from September 2014 to December 2014. The purpose of this study was 1) Determine the effect of giving various doses of oil palm long ash (AJKS) to the growth and production of tomato plants in peat soils, 2) Obtaining a dose of oil palm longitudinal ash AJKS) is best for the growth and production of tomato plants in peat lands.

The study was conducted using a completely randomized design with 6 treatments and 4 replications, namely a dose of 0 tons / ha, a dose of 0.6 tons / ha, a dose of 0.9 tons / ha, a dose of 1.2 tons / ha and a dose of 1.5 tons / ha Ha. The results of the research data were calculated statistically by using analysis of variance and if there was a real effect then a Tukey HSD test was carried out at the 5\% level. The parameters observed in the study were plant height, number of plant branches, weight of planted fruit, weight of grains of fruit, number of planted fruit and diameter of planted fruit.

The results of the study had a significant effect on the parameters of plant height, number of plant branches, weight of planted fruit and number of planted fruit, while parameters of grain fruit and diameter of planted fruit did not have a significant effect. The results showed the best 
AJKS dose was 1.5 tons / ha as seen from the parameters of plant height, number of plant branches, weight of planted fruit, number of planted fruit and diameter of planted fruit

Keywords: Palm Oil Long Ash, Peatlands and Tomatoes

\section{PENDAHULUAN}

Buah tomat merupakan komoditas penting dalam menunjang ketersediaan pangan dan kecukupan gizi masyarakat karena kaya dengan gizi diantaranya mengandung protein, karbohidrat, $\mathrm{Ca}, \mathrm{Fe}, \mathrm{Mg}$ g, dan vitamin C ( $\pm 21 \mathrm{mg})$, serta vitamin $A$, fosfat, kalium. Kadar vitamin A dan C pada tomat akan meningkat seiring dengan peningkatan kemasakan buah (Supriati \& Siregar, 2012).

Nilai gizi yang tinggi menyebabkan kebutuhan atau permintaan pasar juga semakin tinggi, fakta tersebut dapat dilihat di pasar tradisional di kabupaten Indragiri Hilir, pengadaan buah tomat pada waktu waktu tertentu mengalami kelangkaan karena sumber pangadaan (produsen) buah tomat pada umumnya didatangkan dari provinsi Sumatera Barat, relatif sangat sedikit bahkan hampir tidak ada dihasilkan dari proses budidaya yang dilakukan petani lokal, selain itu pada saat tertentu pasokan buah tomat sedikit atau tidak tersedia di pasaran menyebabkan harga tomat bisa melonjak.

Euroconsult (1997) bahwa tanah gambut memiliki reaksi tanah yang masam, ketersediaan hara makro dan mikro yang rendah, asam organik yang dihasilkan tinggi sehingga meracuni tanaman, kapasitas tukar kation yang tinggi dan kejenuhan basa yang rendah serta drainase yang buruk menyebabkan tanah gambut memerlukan penanganan yang baik.

Noor (2001) menyatakan bahwa produktifitas tanaman pangan, palawija dan hortikultura dilahan gambut/bergambut di kalimantan dan sumatera memiliki prospek yang baik. Lahan gambut pasang surut memiliki produktifitas yang relatif lebih tinggi di bandingkan gambut pedalaman yangdisebabkan oleh perbedaan tingkat kesuburan dan sifat kimia yang berbeda. Shah dkk (1989) dalam setiadi (1999) kisaran hasil dan intensitas pertanaman hortikultura dilahan gambut kalimantan barat untuk tanaman tomat berkisar 28 ton/ hektar.

Hasil penelitian Nelvia (1997) bahwa Abu janjang kelapa sawit adalah amelioran yang memberikan hasil terbaik dibandingkan bahan amelioran kapur dan abu vulkanik dalam meningkatkan serapan hara makro $\mathrm{P}$, $\mathrm{K}$, Ca dan Mg selanjutnya Irianto (2009) melaporkan bahwa dari semua perlakuan berbagai jenis abu yang dicobakan bahwa perlakuan abu janjang kelapa sawit memberikan pertumbuhan dan hasil tanaman mentimun terbaik dibandingkan jenis abu lainnya seperti abu sekam padi dan abu tempurung.

Abu janjang kelapa sawit juga dapat meningkatkan kesuburan tanah melalui perbaikan sifat fisik, kimia dan biologi tanah gambut. oleh sebab itu dalam upaya meningkatkan produktifitas tanaman tomatdilahan gambut penggunaan amelioran AJKS merupakan suatu inovasi teknologi yang diharapkan mampu dalam mengatasi permasalahan produktifitas dan efisiensi pemupukan dilahan gambut.

Penelitian bertujuan untuk mengetahui pengaruh dan mendapatkan dosis abu janjang kelapa sawit yang sesuai terhadap pertumbuhan dan produksi tanaman tomat di tanah gambut.

\section{TINJAUAN PUSTAKA}

\subsection{Tanaman tomat}

Tanaman tomat dapat tumbuh di berbagai ketinggian tempat, curah hujan yang sesuai untuk pertumbuhannya berkisar 750 mm - 1250 mm/tahun, curah hujan yang tinggi dapat menghabat persarian. Suhu udara rata -rata harian yang optimal untuk pertumbuhan pada siang hari adalah $18-29{ }^{\circ} \mathrm{C}$ dan pada malam hari $10-20{ }^{\circ} \mathrm{C}$, kelembaban relatif yang tinggi berkisar $25 \%$ akan merangsang pertumbuhan tanaman tomat yang masih muda karena asimilasi 
CO2 menjadi lebih baik melalui stomata yang membuka lebih banyak (Fitriani, 2012).

Media tanam yang ideal bagi pertumbuhan tanaman harus memenuhi beberapa persyaratan diantaranya : bersifat porous sehingga mudah membuang air yang berlebihan, berstruktur gembur subur dan dapat menyimpan air yang cukup untuk pertumbuhan tanaman. Selain itu media tanam juga tidak memiliki kadar salinitas yang rendah, dengan keasaman tanah yang netral hingga alkalis ( $\mathrm{pH} \mathrm{6-7),} \mathrm{dan} \mathrm{tidak}$ mengandung mikroorganisme penyebab hama dan penyakit, media juga mengandung bahan kapur atau unsur yang kaya kalsium. (Pentury, 2001).

\subsection{Karakteristik dan Kendala Media Tumbuh dari Tanah Gambut}

Tanah gambut berasal dari bahan induk organik. Tanah gambut mempunyai ciri dan sifat yaitu tidak terjadi deferensiasi horizon secara jelas, ketebalan lebih dari 0,5 meter, warna coklat hingga kehitaman, tekstur debu lempung, tidak berstruktur, konsistensi tidak lekat-agak lekat, kandungan organik lebih dari 30\% untuk tanah tekstur pasir, umumnya bersifat sangat asam $(4,0)$ kandungan unsur hara sangat rendah (Noor, 2001).

Menurut Noor (2001) kendala yang sering ditemukan pada gambut adalah sebagai berikut : (1) reaksi tanah tergolong sangat masam yang berasal dari berbagai asam organik yang terbentuk selama pelapukan, (2) kandungan hara makro dan mikro rendah, (3) kapasitas tukar kation yang tinggi sedangkan kejenuhan basa endah sehingga kation kation $\mathrm{Ca}, \mathrm{Mg}$ dan $\mathrm{K}$ sukar tersedia bagi tanaman, (4) kandungan asam asam organik tanah tinggi yang berpengaruh langsung dan dapat meracuni tanaman, terutama asam fenolat, (5) tata air yang buruk.

\subsection{Abu Janjang Kelapa Sawit (AJKS)}

Abu janjang berasal dari janjang kosong atau tandan kosong kelapa sawit yang berasal dari tandan buah segar (TBS) setelah buah di rontokkan. Tandan kosong ini merupakan limbah padat organik dari pabrik sawit. Pembuangan limbah ini di area pabrik sawit merupakan kendala karena volumenya sangat besar, sehingga dalam pengakumulasiannya membutuhkan area yang luas. Untuk mengatasi masalah ini dilakukan pembakaran tandan kosong tersebut dalam incinerator (tanur)yang di bangun di sekitar pabrik Abu tandan kosong dari hasil pembakara ini lebih mudah di akumulasikan, biaya angkut lebih murah dan tidak membutuhkan tempat yang luas.

Abu janjang kelapa sawit bersifat sangat alkalis ( $\mathrm{pH}=12)$, sangat higroskopis, mudah dalam menyerap uap air dari udara, hara yang terkandung di dalamnya abu janjang kelapa sawit sangat mudah larut di dalam air sehingga abu janjang harus cepat di aplikasikan (tidak boleh di simpan lama). Sifat abu janjang kelapa sawit menurut Lahuddin (1989) berperan dalam peningkatan $\mathrm{pH}$ pada tanah masam.

Hasil analisis AJKS di Laboratorium Ilmu Tanah Universitas Bengkulu, yang berasal dari janjang sawit di PT Bio Nusantara Bengkulu Utara menunjukkan bahwa kandungan $\mathrm{K}$ sebesar $26,3 \%$ dan $\mathrm{P}$ sebesar 13,74\%. Sedangkan Hasil penelitian PT. Kresna Duta Agroindo (2002) menunjukkan bahwa abu janjang kelapa sawit mengandung kalium yang tinggi (33 $40 \% \mathrm{~K}_{2} \mathrm{O}$ ) bersifat higrokopis dan alkalis sehingga dapat meningkatkan $\mathrm{pH}$ tanah dan mengandung $\mathrm{P}, \mathrm{Ca}, \mathrm{Mg}$ dan unsur - unsur makro lainnya.

\section{METODOLOGI PENELITIAN}

Penelitian dilakukan di kebun percobaan SMK N 1 Kempas Desa Rumbai jaya Kecamatan Kempas Kabupaten Indragiri Hilir, pada ketinggian lahan 7 meter dpl, dengan tipe luapan pasang surut $\mathrm{C}$ dan iklim tergolong basah ( $>200 \mathrm{~mm}$ ) 4 bulan dan bulan kering (<2 $200 \mathrm{~mm}$ ) 8 bulan. selanjutnya untuk analisis sifat kimia tanah dilakukan di laboratorium tanah Institut Pertanian Bogor (IPB). Penelitian dilaksanakan selama 4 bulan dimulai pada September sampai Desember 2014.

Bahan yang digunakan adalah benih tomat varietas SL 975, Polybag berukuran 35 x $45 \mathrm{~cm}$, Ajir Bambu, tanah gambut, pasir, pupuk kandang, pupuk Urea, SP36, KCL, Insetisida Dharmabas dan Herbisida Ken-UP 
serta Abu Janjang Kelapa Sawit (AJKS) yang diperoleh dari pabrik kelapa sawit PT. Bumi Palma kecamatan Enok kabupaten Indragiri Hilir. Alat yang digunakan dalam penelitian ini terdiri dari cangkul, parang, sprayer, gembor, meteran, jangka sorong dan alat tulis lainnya.

Penelitian di laksanakan secara eksprimen dengan menggunakan Rancangan Acak Lengkap (RAL), dengan 6 taraf perlakuan dengan 4 ulangan sehingga terdapat 24 unit percobaan. Data yang diperoleh dianalisis secara statistik dengan analisis ragam dengan model linear. Untuk mengetahui perbedaan antara perlakuan dilakukan Uji Lanjut Tukey HSD pada taraf $5 \%$ dengan menggunakan statistik 8.0.

\section{HASIL DAN PEMBAHASAN}

\subsection{Sifat Kimia Tanah}

Hasil analisa tanah sebelum dilakukan pemberian AJKS yang dijadikan media percobaan berlokasi di desa Rumbai Jaya Kecamatan Tempuling Kabupaten Indragiri Hilir disajikan pada tabel berikut :

Tabel 1. Hasil Analisis sifat kimia tanah gambut desa Rumbai jaya kecamatan Tempuling Kabupaten Indragiri Hilir Propinsi Riau

\begin{tabular}{|l|c|c|c|c|}
\hline No & Hasil analisis & Satuan & Nilai & Kriteria \\
\hline 1. & $\mathrm{pH} \mathrm{H2O}$ & - & 4,8 & Kriteria \\
\hline 2. & $\mathrm{C} / \mathrm{N}$ & - & 31 & masam \\
\hline 3. & $\begin{array}{c}\text { Kejenuhan } \\
\text { basa }\end{array}$ & $\%$ & 62 & $\begin{array}{c}\text { sangat } \\
\text { tinggi }\end{array}$ \\
\hline 4. & N-Total & $\%$ & 0,38 & - \\
\hline 5. & P-tersedia & $\mathrm{Ppm}$ & 22,4 & sedang \\
\hline 6. & C- Organik & $\%$ & 11,93 & sedang \\
\hline 7. & KTK & $\mathrm{cmol} / \mathrm{kg}$ & 37,35 & $\begin{array}{c}\text { sangat } \\
\text { tinggi }\end{array}$ \\
\hline 8. & $\mathrm{Ca}$ & $\mathrm{cmol} / \mathrm{kg}$ & 12,69 & sedang \\
\hline 9. & $\mathrm{Mg}$ & $\mathrm{cmol} / \mathrm{kg}$ & 8,76 & rendah \\
\hline 10. & $\mathrm{~K}$ & $\mathrm{cmol} / \mathrm{kg}$ & 0,61 & rendah \\
\hline 11. & $\mathrm{Na}$ & $\mathrm{cmol} / \mathrm{kg}$ & 1,07 & rendah \\
\hline
\end{tabular}

Sumber : Laboratorium Tanah Institut Pertanian Baogor 15 November - 1 Desember 2014

Dari hasil analisis sampeltanah yang diambil menunjukkan bahwa tanah yang digunakan bereaksi masam dengan $\mathrm{pH}$ 4,8. Kemasaman tanaah tersebut sangat berhubungan dengan Nisabah $\mathrm{C} / \mathrm{N}$ yang sangat tinggi yaitu 31 yang berarti bahwa bahan organik masih dalam proses dekomposisi. Kaandungan unsur unsur hara yang ada didalam tanah gambut seperti unsur $\mathrm{N}$ memiliki kriteria sedang dan Corganik termasuk kategori sangat tinggi. Dilihat dari kandungan unsur $\mathrm{P}$ tersedia berkategori sedang sedangkan unsur $\mathrm{K}$ dan Na termasuk kategori rendah sampai sedang, Ca dan Mg berkategori sangat rendah sampai dengan reendah berdasarkan Kriteria ciri kimia tanah Pusat Penelitian Tanah dan Agrokliat Deptan.

\subsection{Sifat Kimia AJKS}

Hasil analisis di laboratorium Institut Pertanian Bogor pada sampel AJKS yang digunakan pada penelitian ini dapat dilihat pada tabel berikut ini :

Tabel 2. Hasil analisis kandungan hara Abu janjang Kelapa sawit

\begin{tabular}{|c|c|c|c|c|}
\hline No & Kandungan & Satuan & Nilai & $\begin{array}{c}\text { Syara } \\
t \\
\text { Mutu } \\
\text { Perm } \\
\text { entan } \\
\text { Tahun } \\
2011\end{array}$ \\
\hline 1. & $\mathrm{pH}$ & - & 9,9 & $4-9$ \\
\hline 2. & $\mathrm{P}_{2} \mathrm{O}_{5}$ & $\%$ & 0,84 & \multirow{3}{*}{$\begin{array}{c}\text { Hara } \\
\text { makr } \\
\mathrm{O} \\
(\mathrm{N}+ \\
\mathrm{P}_{2} \mathrm{O}_{5} \\
+ \\
\left.\mathrm{K}_{2} \mathrm{O}\right) \\
\mathrm{Minim} \\
\text { al } 4 \\
\end{array}$} \\
\hline 3. & $\mathrm{~K}_{2} \mathrm{O}$ & $\%$ & 5,45 & \\
\hline 4. & $\mathrm{~N}$ & $\%$ & 0,07 & \\
\hline 5. & $\mathrm{Ca}$ & $\begin{array}{c}\mathrm{cmol}(+) / \\
\mathrm{kg}\end{array}$ & 19,27 & \\
\hline 6. & $\mathrm{Mg}$ & $\begin{array}{c}\mathrm{cmol}(+) / \\
\mathrm{kg}\end{array}$ & 6,04 & \\
\hline 7. & $\mathrm{Na}$ & $\begin{array}{c}\mathrm{cmol}(+) / \\
\mathrm{kg}\end{array}$ & 1,06 & \\
\hline
\end{tabular}

Sumber : Laboratorium Tanah Institut Pertanian Bogor 15 November - 1 Desember 2014

Tabel 2 menunjukkan AJKS memiliki $\mathrm{pH}$ 9,9 dan telah memenuhi nsyarat mutu sehingga berpengaruh terhadap ketersediaan sumber hara makro N,P dan $K$ yang seimbang selanjutnya kandungan unsur hara makro yang terdapat pada AJKS adalah 6,36 $(0,84+5,45+0,07)$ dan berkisar di atas 4 atau sudah memenuhi syarat mutu. Dari sumber hara makro tersebut hanya kandungan $\mathrm{N}$ yang persentasenya masih di bawah 0,007 \% dan perlu penambahan sumber pupuk Nitrogen lainnya untuk meningkatkan pertumbuhan vegetatif tanaman. 


\subsection{Tinggi Tanaman (cm)}

Tabel 1. Pengaruh berbagai dosis AJKS terhadap tinggi tanaman tomat (solanum lycopersicum L) di tanah gambut

\begin{tabular}{lc}
\hline Perlakuan & Tinggi tanaman $(\mathrm{cm})$ \\
\hline Tanpa perlakuan & $91.750 \mathrm{~b}$ \\
Dosis $300 \mathrm{~kg} / \mathrm{ha}$ & $107.00 \mathrm{ab}$ \\
Dosis $600 \mathrm{~kg} / \mathrm{ha}$ & $106.75 \mathrm{ab}$ \\
Dosis $900 \mathrm{~kg} / \mathrm{ha}$ & $110.00 \mathrm{ab}$ \\
Dosis $1.200 \mathrm{~kg} / \mathrm{ha}$ & $118.25 \mathrm{ab}$ \\
Dosis $1.500 \mathrm{~kg} / \mathrm{ha}$ & $125.00 \mathrm{a}$ \\
\hline
\end{tabular}

$\mathrm{KK}=63,21 \%$

Keterangan : Angka angka yang diikuti oleh huruf kecil yang sama menunjukkan tidak berbeda nyata pada taraf 5\% menurut uji Tkey HSD.

Tabel 1 menunjukkan bahwa tinggi tanaman pada perlakuan 1,5 ton/ha berbeda tidak nyata dengan perlakuan 1,2 ton/ha, 0.6 ton/ha, 0,6 ton/ha, dan 0,3 ton/ha, namun berbeda nyata dengan tanpa perlakuan AJKS selanjutnya dilihat dari angka tinggi tanaman perlakuan 1,5 ton/ha memiliki tinggi tanaman tertinggi yaitu $125,00 \mathrm{~cm}$ dan tanpa perlakuan AJKS memiliki tinggi tanaman terendah yaitu $91,750 \mathrm{~cm}$. Perbedaan tinggi tanaman antara dosis yang tertinggi 1,5 ton/hadengan tanpa pemberian AJKS adalah 27,25 cm, sedangkan dengan dosis AJKS terendah 0,3 ton/ha adalah $15 \mathrm{~cm}$, sehingga pemberian AJKS dengan berbagai dosis memberikan perbedaan tinggi tanaman tomat berkisar antara $15 \mathrm{~cm}$ sampai dengan $27,25 \mathrm{~cm}$.

Dari fakta tersebut menunjukkan bahwa pemberian AJKS akanmemberikan pertumbuhan lebih tinggi dibandingkan tanpa pemberian AJKS hal ini di sebabkan pemberian AJKS telah memberikan peningkatan $\mathrm{pH}$ tanah gambut yang berdasarkan hasil analisis kimia sebelum bemberian AJKS tegolong sedang yaitu 4,8. Penjaitan et al (1983) dalam Sari (2013) mengemukakan AJKS mengandung basa basa yang dapat menghasilkan ion $\mathrm{OH}$ dalam larutan tanah. Ion $\mathrm{OH}$ akan menetralkan ion $\mathrm{H}^{+}$dari larutan tanah sehingga akan meningkatkan pHdan kation kation lainnya.

\subsection{Jumlah Cabang Tanaman}

Analisis sidik ragam pengaruh pemberian beberapa dosis pupuk AJKS memberikan pengaruh yang nyata terhadap jumlah cabang (Lampiran 3B). Hasil uji lanjut jumlah cabang tomat disajikan pada Tabel 2

Tabel 2. Pengaruh berbagai dosis AJKS terhadap jumulah cabang tanaman tomat (solanum ly copersicum $L$ ) di tanah gambut

\begin{tabular}{ll}
\hline Perlakuan & Jumlah Cabang \\
\hline Tanpa perlakuan & $3.8500 \mathrm{c}$ \\
Dosis $300 \mathrm{~kg} / \mathrm{ha}$ & $4.0750 \mathrm{bc}$ \\
Dosis $600 \mathrm{~kg} / \mathrm{ha}$ & $4.4000 \mathrm{abc}$ \\
Dosis $900 \mathrm{~kg} / \mathrm{ha}$ & $4.5750 \mathrm{ab}$ \\
Dosis $1.200 \mathrm{~kg} / \mathrm{ha}$ & $4.7000 \mathrm{ab}$ \\
Dosis $1.500 \mathrm{~kg} / \mathrm{ha}$ & $4.9000 \mathrm{a}$ \\
\hline KK $=59,18 \%$ & \\
\hline Keterangan : Angka angka yang di ikuti oleh huruf \\
kecil yang sama menunjukkan tidak berbeda nyata \\
pada taraf 5\% menurut uji Tukey HSD
\end{tabular}

Tabel 2 terlihat bahwa pemberian AJKS pada dosis 1,5 ton/ha menunjukkan perbedaan yang nyata dengan tanpa perlakuan AJKS dan dosis AJKS terkecil yaitu dosis 0,3 ton/ha namun pada dosis 0,6 ton/ha, 0,9 ton/ha dan 1,2 ton/ha menunjukkan berbeda tidak nyata, sedangkan dilihat dari rata rata jumlah cabang tanpa perlakuan memiliki rata rata jumlah cabang terbanyak dari seluruh perlakuan pemberian AJKS yaitu 4,9. Kemudian dilihat dari pemberian dosis AJKS semakin tinggi dosis AJKS memiliki kecenderungan semakin banyak jumlah cabang tanaman tomat.

\subsection{Diameter buah (cm)}

Analisis sidik ragam pengaruh pemberian beberapa dosis pupuk AJKS terhadap diameter buah tidak berpengaruh yang nyata, ditanah gambut. Hasil uji lanjut diameter buah tanaman tomat disajikan pada tabel 3 :

Tabel 3. Pengaruh berbagai dosis AJKS terhadap diameter buah tanaman tomat (solanum lycopersicum L) di tanah gambut

\begin{tabular}{lc}
\hline Perlakuan & Diameter Buah \\
\hline Tanpa Perlakuan & $4,88 \mathrm{a}$ \\
Dosis $300 \mathrm{~kg} / \mathrm{ha}$ & $4,69 \mathrm{a}$ \\
Dosis $600 \mathrm{~kg} / \mathrm{ha}$ & $4,56 \mathrm{a}$ \\
Dosis $900 \mathrm{~kg} / \mathrm{ha}$ & $4,37 \mathrm{a}$ \\
Dosis $1200 \mathrm{~kg} / \mathrm{ha}$ & $4,06 \mathrm{a}$ \\
Dosis $1500 \mathrm{~kg} / \mathrm{ha}$ & $3,81 \mathrm{a}$ \\
\hline KK $=10,44 \%$ & \\
\hline
\end{tabular}


Keterangan : Angka angka yang diikuti huruf kecilyang sama menunjukan tidak berbeda nyata pada taraf $5 \%$ menurut uji Tukey HSD

Dari tebel diatas terlihit bahwa masing masing perlakuan berbagai dosis AJKS memperlihatkan berbeda tidak nyata, seddangkan dilihat dari angka rata rata hasil percobaan diameter buah tomat tertinggi adalah pada perlakuan AJKS dengan dosis 1,5 ton/ ha yaitu $4,88 \mathrm{~cm}$ sedangkan rata rata diameter buah tomat terendah yaitu pada tanpa pemberian AJKS yaitu $3,81 \mathrm{~cm}$.

Pemberian AJKS dengan dosis yang tinggi akan memberikan dampak terhadap kesuburun tanah seperti dikemukakan oleh Hakim et al, 1988 bahwa pemberian Bahan organik didalam tanah ada yang memiliki sifat langsung terhadap tanaman, tetapi sebagian besar mempengaruhi tanaman melalui perubahan sifat dan ciri tanah.

\subsection{Jumlah buah Per Tanaman (butir)}

Analisis sidik ragam pengaruh pemberian bebeapa dosis puuk AJKS terhadap jumlah buah per tanaman memperlihatkan pengaruh yang nyata (lampiran 4E), sedangkan untuk melihat perbedaan masing masing rata rata perlakuan dapat dilihat pada tabel 4 :

Tabel 4. Pengaruh berbagai dosis AJKS terhadap jumlah buah per tanaman tanaman tomat (solanum lycopersicum L) di tanah gambut

\begin{tabular}{lc}
\hline Perlakuan & Jumlah buah per tanaman \\
\hline Tanpa perlakuan & $4,25 \mathrm{c}$ \\
Dosis $300 \mathrm{~kg} / \mathrm{ha}$ & $6,25 \mathrm{bc}$ \\
Dosis $600 \mathrm{~kg} / \mathrm{ha}$ & $6,25 \mathrm{bc}$ \\
Dosis $900 \mathrm{~kg} / \mathrm{ha}$ & $9,50 \mathrm{abc}$ \\
Dosis $1200 \mathrm{~kg} / \mathrm{ha}$ & $12,25 \mathrm{ab}$ \\
Dosis $1500 \mathrm{~kg} / \mathrm{ha}$ & $12,75 \mathrm{a}$ \\
\hline
\end{tabular}

$\mathrm{KK}=33,36 \%$

Keterangan : Angka angka yang diikuti oleh huruf kecil yang sama menunjukan tidak berbeda nyata pada taraf 5\% menurut uji Tukey HSD

Tabel 4 terlihat bahwa tanpa pemberian AJKS memiliki rata rata jumlah buah pertanaman yang rendah yaitu 4,25 dibandingkan pemberian perlakuan berbagai dosis AJKS, sedangkan pemberian AJKS memiliki rata rata jumlah buah pertanaman yang rendah yaitu 4,25 dibandingkan pemberian perlakuan berbagai dosis AJKS, sedangkan pemberian dengan dosis 1,5 ton/ha menunjukkan rata rata jumlah buah pertanaman tertinggi yaitu 12,75 .

Selain pengaruh langsung dari AJKS juga dipengaruhi oleh perbaikan pada lingkungan tumbuh tanaman tomat selama siklus tumbuhnya sehingga akan meningkatkan efisiensi pemupukan dan dengan efesiensi pemupukan maka akan meningkatkan jumlah buah pertanaman tomat seperti yang di kemukakan oleh Purnomo (2001), bahwa pemberian amelioran akan memberikan dampak terhadap peningkatan peningkatan efesiensi pemupukan. peningkatan efesiensi pemupukan secara sinergis akan memberikan efek terhadap perbaikan pertumbuhan tanaman dan peningkatan komponen hasil.

\subsection{Bobot buah perbutir (gram)}

Analisis sidikragam pengaruh pemberian beberapa dosis pupuk AJKS terhadap bobot buah perbutir tanaman tomat tidak memperlihatkan pengaruh yang nyata (lampiran 4D) sedangkan rata rata masing masing perlakuan beberapa dosis AJKS terhadap bobot buah perbutir dapat di lihat tabel 5:

Tabel 5 Pengaruh berbagai dosis AJKS terhadap bobot buah perbutir tanaman tomat (solanum lycopersicum $L$ ) di tanah gambut

\begin{tabular}{lc}
\hline Perlakuan & Bobot buah perbutir (gram) \\
\hline Tanpa perlakuan & $25,6 \mathrm{~A}$ \\
Dosis $300 \mathrm{~kg} / \mathrm{ha}$ & $24,2 \mathrm{~A}$ \\
Dosis $600 \mathrm{~kg} / \mathrm{ha}$ & $23,6 \mathrm{~A}$ \\
Dosis $900 \mathrm{~kg} / \mathrm{ha}$ & $24,1 \mathrm{~A}$ \\
Dosis $1200 \mathrm{~kg} / \mathrm{ha}$ & $26,9 \mathrm{~A}$ \\
Dosis $1500 \mathrm{~kg} / \mathrm{ha}$ & $23,9 \mathrm{~A}$ \\
\hline KK $=1,31 \%$ & \\
\hline Ketrangan : Angka angka yang diikuti oleh huruf \\
kecil yang sama menunjukkan tidak berbeda nyata \\
pada taraf $5 \%$ menurut uji Tukey HSD.
\end{tabular}

Dari tabel 5 tersebut terlihat bahwa bobot perbutir tanaman tomat pada berbagai perlakuan menunjukkan berbeda tidak nyata, namun secara angka tanpa pemberian AJKS Menunjukkan rata rata bobot buah perbutir terendah yaitu 23,6 gram, sedangkan dosis AJKS 1,2 ton/ha menunjukkan rata rata bobot buah perbutir tertinggi yaitu 26,9 gram. 
Berbeda tidak nyata rata rata berbagai perlakuan dosis AJKS tersebut diduga disebabkan oleh faktor keseragaman varietas atau genetik tanaman pada percobaan yang telah dilakukan menggunakan varietas yang sama dari masing masing perlakuan berbagai dosis AJKS, fakta tersebut dengan penrnyataan Asni N dan Yardha (2004) bahwa perbedaan berat komponen hasil sangat dipengaruhi oleh perbedaan varietas selanjutnya ditambahkan oleh Kasno et al (1987) juga mengemukakan bahwa sifat genetik yang sama pada tanaman sangat berkaitan dengan keseragaman komponen hasil tanaman.

\subsection{Bobot Buah Pertanaman (gram)}

Analisis sidik ragam pengaruh pemberian beberapa dosis pupuk AJKS terhadap bobotbuah per tanaman memperlihatkan pengaruh yang nyata (lampiran 4D). Sedangkan untuk memperlihatkan perbedaan rata rata masing masing perlakuan terhadap bobot buah pertanaman percobaan dapat dilihat pada tabel 6 :

Tabel 6. Pengaruh berbagai dosis AJKS terhadap bobot buah pertanaman tanaman tomat (solanum lycopersicum $L$ ) di tanah gambut

\begin{tabular}{lc}
\hline Perlakuan $\quad$ Bobot buah pertanaman (gram) \\
\hline Tanpa perlakuan & $100,25 \mathrm{~b}$ \\
Dosis $300 \mathrm{~kg} / \mathrm{ha}$ & $141,54 \mathrm{~b}$ \\
Dosis $600 \mathrm{~kg} / \mathrm{ha}$ & $167,84 \mathrm{ab}$ \\
Dosis $900 \mathrm{~kg} / \mathrm{ha}$ & $217,96 \mathrm{ab}$ \\
Dosis $1200 \mathrm{~kg} / \mathrm{ha}$ & $303,25 \mathrm{a}$ \\
Dosis $1500 \mathrm{~kg} / \mathrm{ha}$ & $308,75 \mathrm{a}$
\end{tabular}

$\mathrm{KK}=37,85 \%$

Ketrangan : Angka angka yang diikuti oleh huruf kecil yang sama menunjukkan tidak berbeda nyata pada taraf 5\% menurut uji Tukey HSD.

Dari tabel tersebut terlihat terjadi perbedaan pengaruh pemberian berbagai dosis AJKS dimana semakin tinggi dosis AJKS yang diberikan berkorelasi peningkatan bobot buah pertanaman. sedangkan di lihat dari rata rata masing masing perlakuan terlihat tanpa pemberian AJKS memperlihatkan rata rata bobot buah pertanaman terendah yaitu 100,25 gram pertanaman sedangkan pemberian dosis 1,2 ton/ha memperlihatkan rata rata bobot buah pertanaman tertinggi yaitu 303,25 gram pertanaman tomat. sedangkan dilihat dari perbedaan rata rata perlakuan tanpa pemberian dosis AJKS memperlihatkan perbedaan yang nyata dengan pemberian dosis AJKS 1,2 dan 1,5 ton/hektar, namun berbeda tidak nyata dengan dosis 0,3 dan 0,6 dan 0,9 ton/ha.

Menurut laktin (1993) suhu mempengaruhi transpirasi dan proses membuka dan menutupnya stomata Salisbury dan Ross (1995) menambahkan bahwa menutupnya stomata pada siang hari menyebabkan proses fiksasi $\mathrm{CO}_{2}$ melalui stomata akan terhambat, sehingga proses fhotosintesa tanaman terhambat karena $\mathrm{CO}_{2}$ sebagai bahan baku fhotosintesis menurun jumlahnya dan akhirnya akan menurunkan hasil fhotosintat tanaman.

Produksi tanaman tergantung pada efisiensi hasil fhotosintesis. menurut Harjadi (1993) fhotosintesis yang terhambat akan menghaasilkan hasil fhotosintat yang rendah yang akan translokasikan untuk pembentukan bunga dan buah, sehingga pembentukan bunga dan buah menjadi menurun dan produksi menjadi rendah.

\section{KESIMPULAN DAN SARAN}

\subsection{Kesimpulan}

Dari hasil penelitian dan pembahasan yang telah dilakukan dapat diambil kesimpulan yaitu sebagai berikut :

1. pemberian dosis AJKS berbeda nyata pada parameter tinggi tanaman, jumla cabang, bobot buah pertanaman dan jumlah buah pertanaman tetapi tidak memberikan pengarh yang nyata terhadap parameter bobot buah perbutir dan diameter buah pertanaman.

2. hasil dari parameter yang diamati teritinggi adalah pada dosis 1,5 ton/ha AJKS yaitu pada parameter tinggi tanaman, jumlah cabang tanaman, bobot buah pertanaman, jumlah buah pertanaman dan diameter buah pertanaman sedangkan untuk nilai rata-rata tertinggi untuk parameter bobot buah perbutir adalah pada dosis 1,2 ton/ha. 


\subsection{Saran}

Dari hasil penelitian yang telah dilakukan disarankan untuk memberikan perlakuan AJKS pada tanaman tomat di media gambut agar bobot buah dan jumlah buah meningkat dan kesuburan tanah gambut dapat meningkat secara berkelanjutan.

\section{DAFTAR PUSTAKA}

Euroconsult, 1997. Integrated Swamp Development Project. IBRD Loan 3755 IND. Pedoman Operasi dan Pemeliharaan. Delta Reteh. Riau.

Fitriani, E. 2012. Budidaya Tomat diberbagai Media. Penerbit Pustaka Baru Press. Noor, M. (2001). Pertanian lahan gambut. Penerbit kanisius. Yogyakarta.

Hakim, N., M. Y. Nyakpa, A. M. Lubis, S. G. Nugroho, M. R. saul, M. A. Diha, G. B. Hong, H. H. Bailey. 1988. Kesuburan Tanah. Universitas Negri Lampung. Lampung

Kusno, A. Bahri, A. Mattjik, S, Solahudin, S Somaatmadja dan Subandi, 1987. Telaah Interaksi genotipe dan lingkungan pada kacang kedelai penelitian palawija 2 : 81- 88 .

Lahuddin, 1989. Pengaruh abu janjang kelapa sawit terhadap B dan Zn tersedia. Buletin I. Pertanian USU. Medan

Laktin, B. 1996.Fisiologi Pertumbuhan dan Perkembangan Tanaman. Raja Grafindo Persada. Jakarta. 218 hal.

Nelvia, 1997. Pemupukan Posphat Alam dan Amelioran pada tanah gambut terhadap ketersediaan dan serapan $\mathrm{P}, \mathrm{K}$, Ca dan $\mathrm{Mg}$ oleh tanaman jagung. dalam : Identifikasi Masalah Pupuk Nasional dan Standarisasi Mutu yang efektif. Prosiding seminar Nasional : Bandar Lampung, 22 Desember 1997. kerjasama Unila dan HITI. 4Hal.
Pentury, D. 2001 Media Pembibitan Kakao. Ambon. Balai Besar perbenihan dan proteksi tanaman perkebunan (www.ditjenbun .deptan.go.id) di akses tanggal 13 Mei 2012.

Purnomo, J. 2001, Kajian Penggunaan Bahan Organik Pada Padi Sawah. Fakultas Pertanian. Universitas Sumatera Utara.

Salisbury, F dan C.W. Ross, 1995. Fisiologi tumbuhan Terjemahan, D. R. dan Sumaryono, ITB. Bandung.

Setiadi,1999. Teknologi pemanfaatan Iahan gambut untuk pertanian. BPP Teknologi-HSF.Jakarta. 